\title{
Microbial Production of Plant Gibberellins and Related Compounds from ent-Kaurene Derivatives in Gibberella fujikuroi
}

\author{
Kojiro Wada, Tetsuya Imai and Hitoshi Yamashita \\ Department of Agricultural Chemistry, Nagoya University, \\ Nagoya 464, Japan \\ Received February 9, 1981
}

\begin{abstract}
ent-15 $\alpha$-Hydroxykaurenoic acid (8) was synthesized and fed to a mycelium suspension of Gibberella fujikuroi in the presence of $1-n$-decylimidazole, a gibberellin biosynthesis inhibitor. The metabolites included $15 \beta$-hydroxy $\mathrm{GA}_{24}, \mathrm{GA}_{45}$ (GA of Pyrus communis), $15 \beta$-hydroxy $\mathrm{GA}_{15}$ and

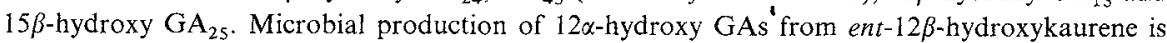
also described.
\end{abstract}

Many gibberellins have been isolated from higher plants. Each of these plant gibberellins may have a specific physiological activity or activities, for example, shoot elongation, stimulation of amylase biosynthesis, setting and development of fruits, and initiation of flowering $e t c{ }^{1)}$ Their specific activities remain to be examined, and practical supply of plant gibberellins is required for the detailed study of gibberellin physiology. However, syntheses of many plant gibberellins still are not accomplished. Recently, we demonstrated that microbial transformation of synthesized entkaurene derivatives by G. fujikuroi in the presence of a gibberellin biosynthesis inhibitor is useful for preparing gibberellins and related compounds in large scale. ${ }^{2)}$ Bearder, ${ }^{3)} \mathrm{Cross}^{4)}$ and Murofushi ${ }^{5)}$ also reported similar microbial transformation of ent-kaurene derivatives in G. fujikuroi.

We wish report here bioorganic productions of plant gibberellins and related compounds through combination of synthesis of entkaurene derivatives and their microbial transformations.

Synthesis and microbial transformation of ent15 $\alpha$-hydroxykaurenoic acid (8)

ent-15 $\alpha$-Hydroxykaurenoic acid (8) was synthesized from ent-kaurenoic acid (1) with six steps as an artificial substrate of the enzyme for gibberelline biosynthesis in G. fujikuroi.

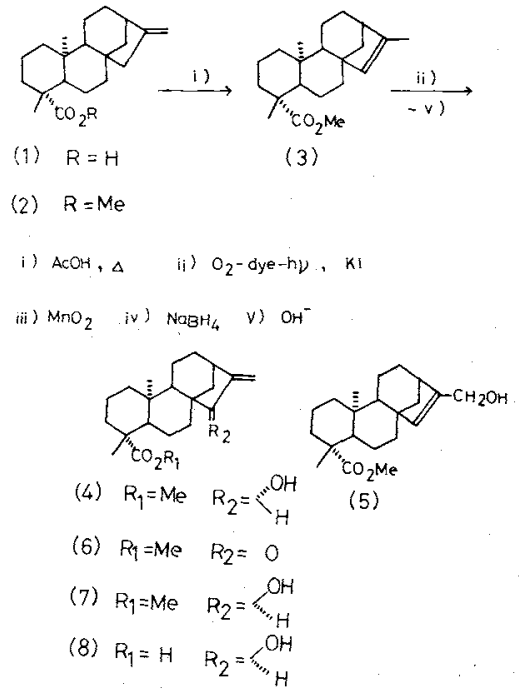

Methyl ester (2) of ent-kaurenoic acid was rearranged to a mixture of the starting material and ent-kaur-15-en-19-oic acid methyl ester (3) by refluxing in acetic acid. The mix-

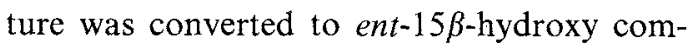
pound (4) and ent-kaur-15-en-17-ol (5) by photooxygenation and reduction following the procedure reported in the literature. ${ }^{6)}$ The ent$15 \beta$-hydroxy compound (4) was oxidized to $\alpha, \beta$-unsaturated ketone (6) with manganese dioxide. $\mathrm{NaBH}_{4}$ reduction and alkaline hydrolysis of the compound (6) gave the ent-15 $\alpha$ hydroxy compound (8). The physicochemical data except melting point of the product was identical with those of an authentic sample. ${ }^{7)}$ 

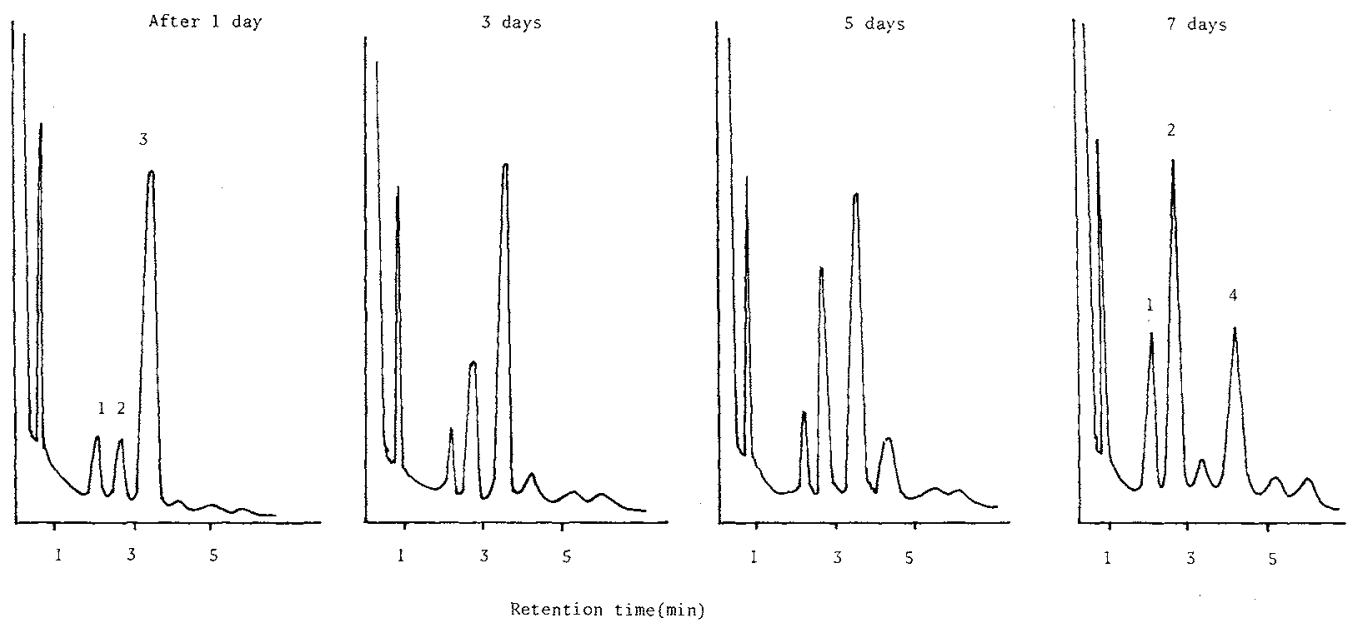

FIG. 1. GC of the Methyl Esters of Acidic Metabolites Produced from ent-15 $\alpha$-Hydroxykaurenoic Acid in G. fujikuroi.

Peak 1, A-III; 2, A-I; 3, ent-7 $\alpha, 15 \alpha$-dihydroxykaurenoic acid; 4, A-IV.

Lowering of melting point of our sample may results from admixture of the dihydroderivative of (8), which is a byproduct formed in the $\mathrm{NaBH}_{4}$ 1,4-reduction of 6. GC-MS of the sample (7) showed the presence of $4 \%$ of the dihydroderivative.

In the preliminary time coarse cultue; ent$15 \alpha$-hydroxykaurenoic acid (8) was incubated with mycelium of $G$. fujikuroi suspended in $\mathrm{N}$ $0 \%$-ICI medium, in which endogenous GA biosynthesis was blocked by the addition of 1 $n$-decylimidazole. Small portion of the culture were removed in the 1st, 3rd, 5th and 7th days, and the crude acidic extracts of these culture filtrate were analyzed by GC-MS. Even in the $24 \mathrm{hr}$ culture, the artificial substrate (8) was completely metabolized to ent-7 $7,15 \alpha$-dihydroxykaurenoic acid (18).

The other metabolites were then formed at the expence of $\mathbf{1 8}$ in longer incubation, and almost all of 18 disappeared in 7 th days (see Fig. 1).

The acidc metabolites $(39 \mathrm{mg}$ ) obtained from the preliminary microbial transformation of $60 \mathrm{mg}$ of the substrate $(\mathbf{8})$ were separated into 7 fractions by silica gel TLC, using a solvent mixture of $\mathrm{CH}_{2} \mathrm{Cl}_{2}-\mathrm{EtOAc}-$ $\mathrm{AcOH}(10: 1: 1)$.

The main GA metabolites (A-I, -III and
-IV) were isolated from the fraction 2 by a reverse phase HPLC (Merk, Lichrosorb RP18, $\mathrm{MeOH} \mathrm{CH}_{3} \mathrm{CN}-1 \% \mathrm{H}_{3} \mathrm{PO}_{4}, \quad 10: 40: 50$ ) (see Figs. 2 and 3).

A large-scale microbial transformation of ent-15 $\alpha$-kaurenoic acid $(8)(1.5 \mathrm{~g})$ was performed under the conditions identical with those of the time coarse culture for 7 days. As shown in Fig. 4, 9 acidic metabolites (A-I to A-IX) were isolated from the extract of the culture filtrate by silica gel TLC and riverse phase HPLC.

The metabolite A-I (9) is a colorless powder, $[\alpha]_{\mathrm{D}}^{32}-81.0^{\circ}$. The methyl ester of A-I, $\mathrm{C}_{22} \mathrm{H}_{30} \mathrm{O}_{6}$, showed hydroxyl $\left(3520 \mathrm{~cm}^{-1}\right)$, carbonyl $(1720-1710)$ and olefinic $(1660,900)$ absorption in its IR spectrum. The ${ }^{1} \mathrm{H}$ NMR spectrum contained one quaternary $\mathrm{Me}$, twoOMe, two olefinic protons, a secondary alcohol, an aldehyde, and the typical gibberellin $\mathrm{AB}$ system $(\delta 2.13$ and $3.96, J=13.1 \mathrm{~Hz})$ assigned to the trans $5-\mathrm{H}$ and $6-\mathrm{H}$ protons. ${ }^{8}$ By addition of $\mathrm{D}_{2} \mathrm{O}$, signal of $\mathrm{C}-15$ proton $(\delta 3.97$, bd) collapsed to a sharp triplet and a hydroxyl proton signal $(\delta 3.42, \mathrm{~d}, J=3.7 \mathrm{~Hz})$ disappeared, suggesting that an intra molecular hydrogen bond between the hydroxyl group at C-15 and C-7 carbonyl group is formed. The MS shows similarities to that of $\mathrm{GA}_{19}$ methyl 


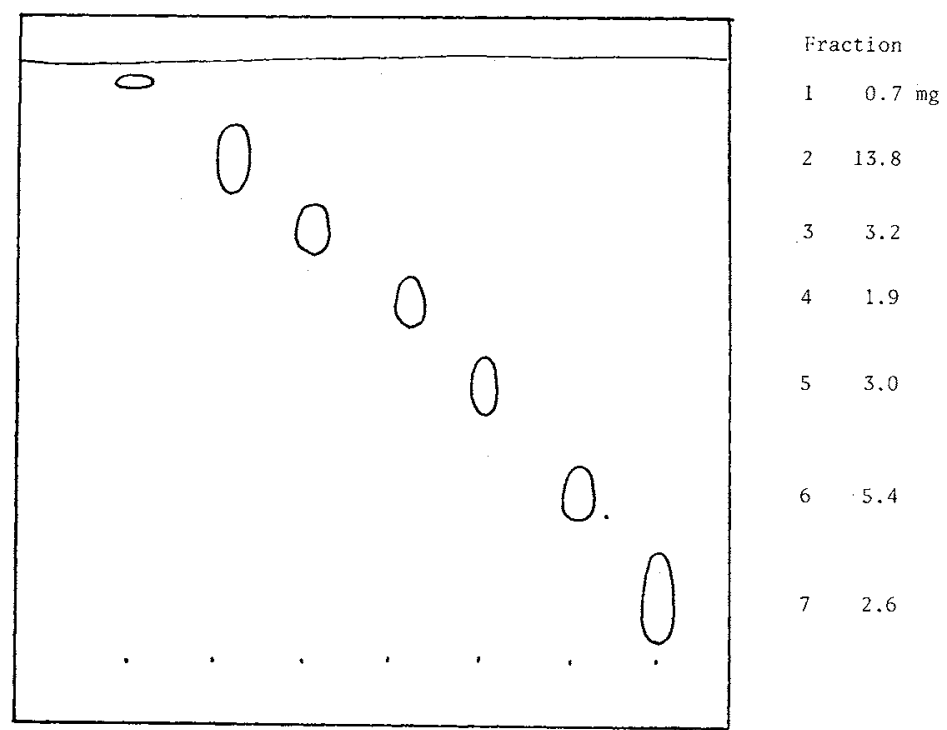

FIG. 2. Silica Gel TLC of the Acidic Metabolites from $8(60 \mathrm{mg})$.

Solvent, $\mathrm{CH}_{2} \mathrm{Cl}_{2}$-EtOAc-AcOH (10:10:1).

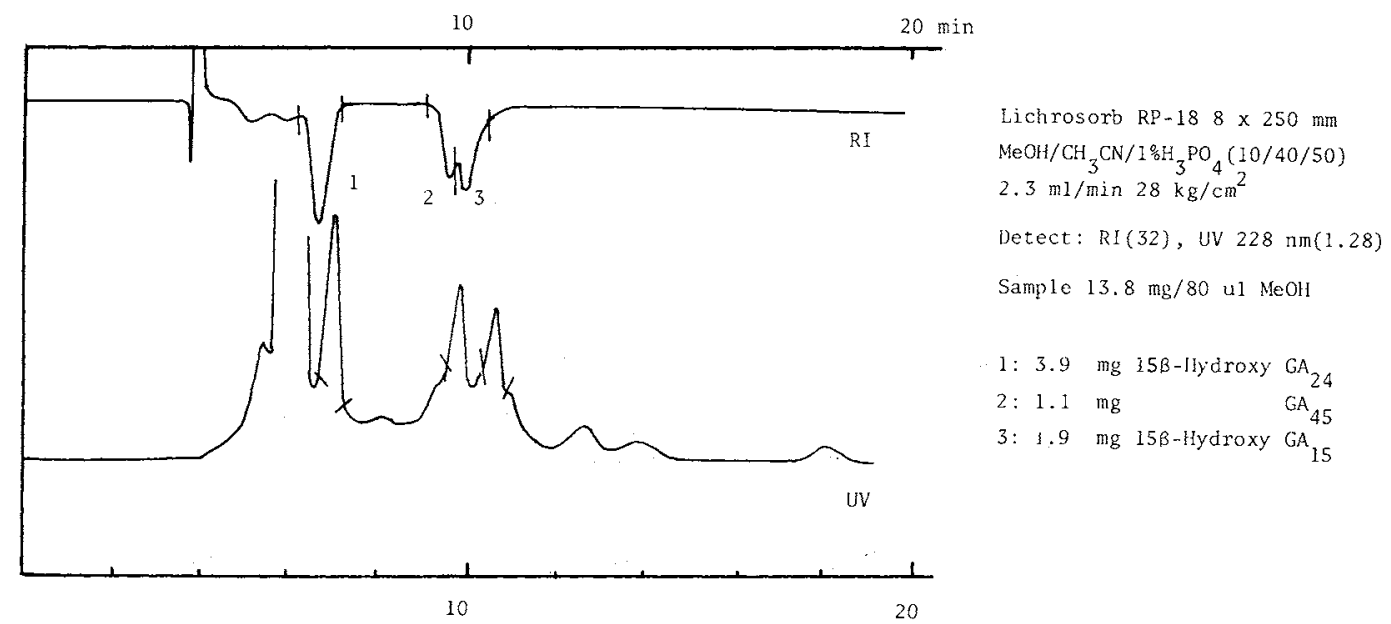

FIG. 3. HPLC Separation of Fraction 2.

ester by possessing ions at M-28, M-32, M-46, M-78, M-88 and M-147/148 characteristic of the loss of two methoxycarbonyl groups and a carbon monoxide from a $\mathrm{C}_{20}$ gibberellin. ${ }^{9)}$ The compound A-I was thus $15 \beta$-hydroxyl $\mathrm{GA}_{24}$.

The second metabolite A-II (10) was isolated as its dimethyl ester $\mathrm{C}_{22} \mathrm{H}_{32} \mathrm{O}_{6}$, which showed hydroxyl $\left(3530 \mathrm{~cm}^{-1}\right)$ and carbonyl (1720-1715) absorption in its IR spectrum. The ${ }^{1} \mathrm{H}$ NMR contained one quaternary Me, one secondary Me, an aldehyde, and a secondary alcohol. Spin decoupling experiments confirmed the presence of the typical gibberellin $\mathrm{AB}$ system $(\delta 2.08$ and 3.86 , $J=12.9 \mathrm{~Hz}$ ) assigned to the C-5 and C-6 protons. The MS was similar to that of A-I dimethyl ester with M-28, M-32, M-46, M-88 and M-147/148 shifted to higher mass by 2 a.m.u. Hence A-II ws assigned the structure (10). This metabolite is presumably derived 


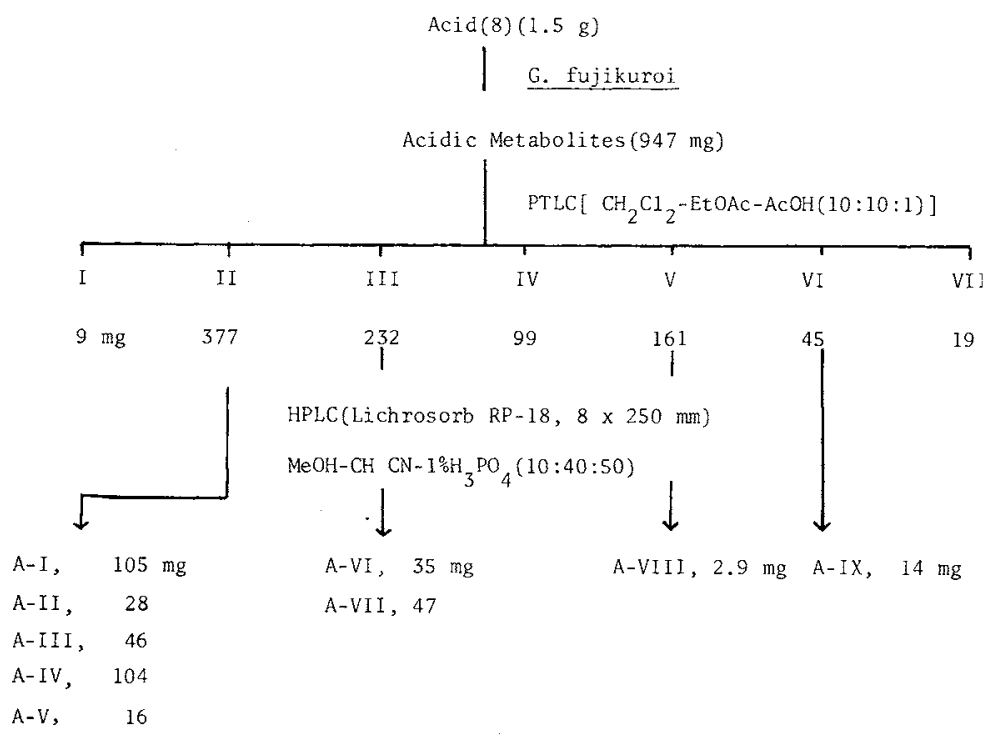

FIG. 4. Isolation of Acidic Metabolites from ent-15 $\alpha$-Hydroxykaurenoic Acid (8).

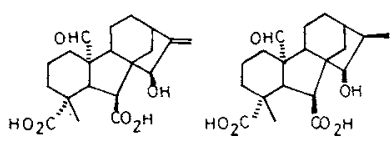

$A-I(9)$

A - If $(10)$

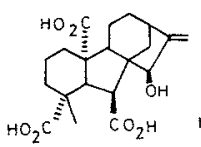

$A-V I(14)$

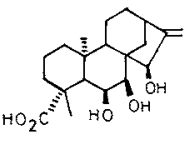

$A-V I I(15)$

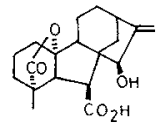

A-

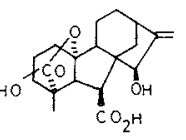

A-VII (16)

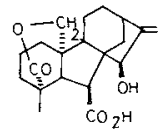

$A-I V(12)$

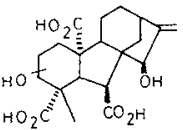

$A-I X(17)$

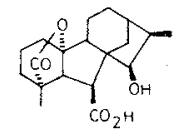

$A-V(13)$

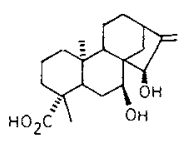

(18)

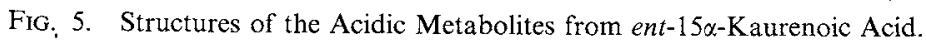

from the dihydroderivative of $\mathbf{8}$ admixed in the artificial substrate.

The metabolite A-III has mp. $204 \sim 205^{\circ} \mathrm{C}$ and $[\alpha]_{D}^{33}-44.0^{\circ}$. The methyl ester of A-III, $\mathrm{C}_{20} \mathrm{H}_{26} \mathrm{O}_{5}$, showed hydroxyl $\left(3500 \mathrm{~cm}^{-1}\right), \gamma$ lactone (1765), ester (1720) and olefinic (1600, 900) absorption in its IR spectrum. In the ${ }^{1} \mathrm{H}$ NMR spectrum, the chemical shifts of the signals $\left(\mathrm{C}_{18}-\mathrm{Me}\right.$, trans $5-\mathrm{H}$ and $\left.6-\mathrm{H}\right)$ were almost identical with those of $\mathrm{GA}_{9}$ methyl ester. The MS of MeTMSi derivative of A-III showed fragmentation pattern and relative intensities of each peaks identical with those of $\mathrm{GA}_{45} \mathrm{MeTMSi}^{10,11)}$ A-III was thus $\mathrm{GA}_{45}$.

The metabolite A-IV has mp $265 \sim 267^{\circ} \mathrm{C}$ and $[\alpha]_{\mathrm{D}}^{29}-66.7^{\circ}$. The methyl ester of IV, $\mathrm{C}_{21} \mathrm{H}_{28} \mathrm{O}_{5}$, showed hydroxyl $\left(3530 \mathrm{~cm}^{-1}\right)$, carbonyl (1720), olefinic $(1600,900)$ absorption in its IR spectrum. The ${ }^{1} \mathrm{H}$ NMR showed proton signals (quaternary $\mathrm{Me},-\mathrm{OCH}_{2}-$ at $\mathrm{C}-20$ and trans $5-\mathrm{H}$ and $6-\mathrm{H}$ ) analogues to $\mathrm{GA}_{15}$ methyl ester. The MS showed ions at M-32, M-60 and M-78 characteristic of the loss of one methoxycarbonyl group. The presence of a significant ion at M-46 is associated with $\delta$ lactone ring in $\mathrm{C}_{20}$ gibberellins. ${ }^{9)}$ The $\mathrm{NaBH}_{4}$ reduction of A-I gave quantitatively A-IV. Thus, A-IV was assigned the structure (12), $15 \beta$-hydroxy $\mathrm{GA}_{15}$.

The metabolite $\mathrm{A}-\mathrm{V}, \mathrm{mp} .232 \sim 233^{\circ} \mathrm{C},[\alpha]_{\mathrm{D}}^{33}$ 


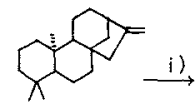

(19)

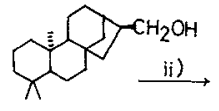

(20)

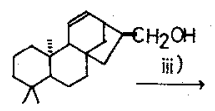

(21)

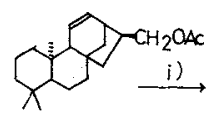

(22)
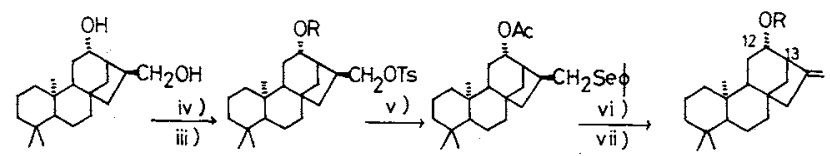

(23)

(24) $\mathrm{R}=\mathrm{H}$

(26)

(27) $R=A C$

(25) $R=A C$

(28) $\mathrm{R}=\mathrm{H}$

i) $\mathrm{NaBH}_{4}, \mathrm{H}_{2} \mathrm{O}_{2}-\mathrm{NaOH}$ ii) $\mathrm{I}_{2}-\mathrm{Po}_{8}\left(\mathrm{OAC}_{4}\right)_{4}$ iii) $A_{2} \mathrm{O}-$ - yyridine

iv) $\mathrm{TsCl}$-Pyridine $v) \phi \mathrm{Se}^{-}$vi) $\mathrm{H}_{2} \mathrm{O}_{2}$ vii) $\mathrm{OH}^{-}$

FIG. 6. Synthesis of ent-12 $\beta$-Hydroxykaur-16-ene.

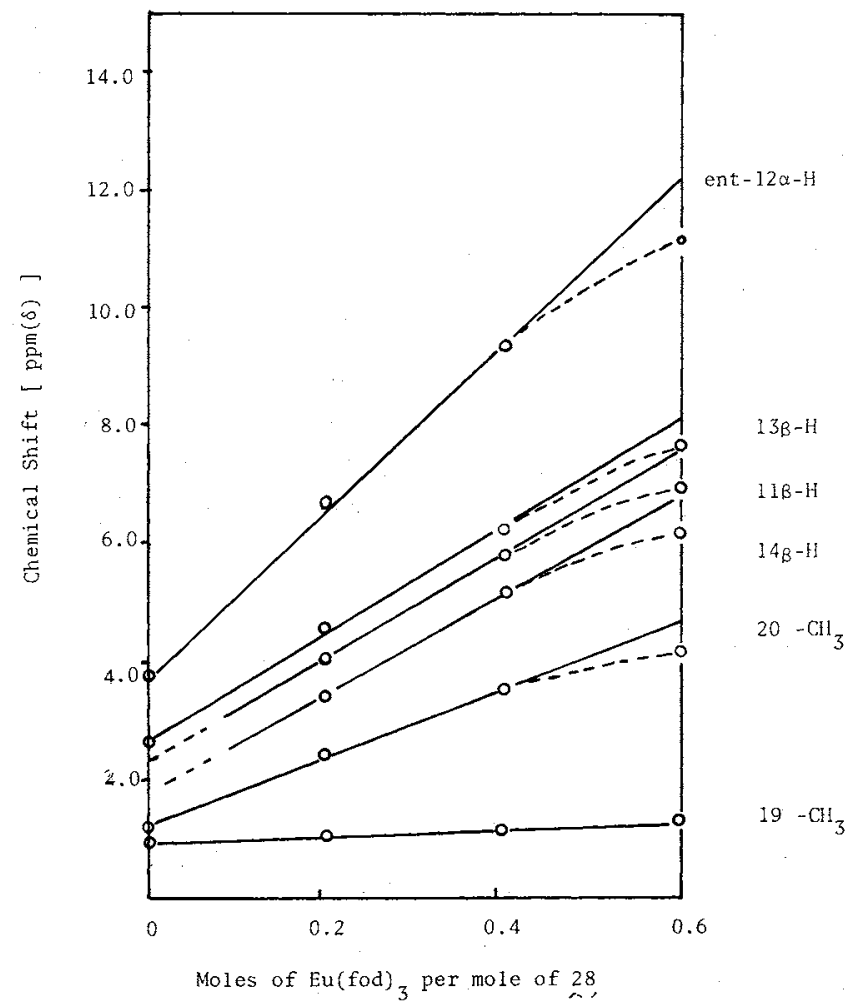

FIG. 7. Variation in the Chemical Shift for the Protons of 28 with Increasing Concentration of Eu(fod) . $_{3}$ Deviations from linearity at high shift reagent concentration originate from the precipitation of $\mathrm{Eu}(\text { fod })_{3}$ from the solution.

$-27.8^{\circ}$, was identified as the dihydroderivative of A-III from the spectral data. The configurations of $\mathrm{C}_{15}-\mathrm{OH}$ and $\mathrm{C}_{16}$-Me group were assigned $c i s$ on $\beta$-side because the coupling constant between $15-\mathrm{H}$ and $16-\mathrm{H}$ was
$10.5 \mathrm{~Hz}^{12)}$ Thus, $\mathrm{A}-\mathrm{V}$ was assigned the structure (13). The ${ }^{1} \mathrm{H}$ NMR of the methyl ester of A-VI showed three OMe signals, and similar to that of $\mathrm{GA}_{25}$ methyl ester. ${ }^{13)}$ The MS showed strong peaks at M-120 and M-180 
characteristic of the loss of three methoxycarbonyl groups from a $\mathrm{C}_{20}$ gibberellin. $\mathrm{A}-\mathrm{VI}$ was thus $15 \beta$-hydroxy $\mathrm{GA}_{25}$ (14). The metabolite VII was assigned ent- $6 \alpha, 7 \alpha, 15 \alpha-$ trihydroxykaurenoic acid (15) from its ${ }^{1} \mathrm{H}$ NMR and the MS of its MeTMSi derivative, which showed signals and fragmentation pattern similar to those of ent-6 $\alpha, 7 \alpha, 13-$ trihydroxykaurenoic acid derivative. ${ }^{3)}$ The ${ }^{1} \mathrm{H}$ NMR spectra of the methyl esters of A-VIII and A-IX were similar to those of the methyl esters of A-III and A-VI, respectively, except the deshielded signals of $5-\mathrm{H}(\Delta \delta 0.63$ and 0.64 ), which show the presence of a hydroxy group on $1 \beta$ or $3 \beta$-position. In addition, the MS of MeTMSi derivatives of both metabolites showed a prominent ion at $m / z 129$, characteristic of the TMSi ether of a 1 or 3hydroxy GA. ${ }^{9)}$ Thus, the metabolites, A-VIII and A-IX were tentatively assigned $1 \beta$ - or $3 \beta$ hydroxy $\mathrm{GA}_{45}(16)$ and $1 \beta, 15 \beta$ - or $3 \beta, 15 \beta$ dihydroxy $\mathrm{GA}_{25}$ (17), respectively.

Synthesis and microbial transformation of ent-

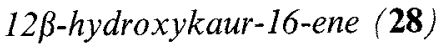

ent-12 $\beta$-Hydroxykaur-16-ene (28) was synthesized from ent-kaurene (19) by eight steps as shown in Fig. 6. The structure of the synthesized material (28) was confirmed as follows: The triplet signal at $\delta 2 . \dot{6} 2(13-\mathrm{H})$ in its ${ }^{1} \mathrm{H}$ NMR collapsed to a doublet on irradiation of the $12-\mathrm{H}$ signal at $3.80 \mathrm{(t}$, $J=4.7 \mathrm{~Hz}$ ). In the ${ }^{1} \mathrm{H}$ NMR of the ketone (29) which was obtained by $\mathrm{CrO}_{3}$-pyridine oxidation of 28 , the $13-\mathrm{H}$ signal shifted to $\delta 3.21$ by the anisotropy of the carbonyl group and appeared as a doublet. The high downfield shifts of proton signals of $\mathrm{C}-11 \alpha,-13,-14 \alpha$ and -20 in the spectra recorded using a concentration ratio of $\mathrm{Eu}$ (fod) $)_{3}$ to 28 of $0.2 \sim 0.6$ indicate that the configuration of the hydroxyl group in 28 is $12 \alpha$ (see Fig. 7).

Microbial transformation of ent-12 $\beta$ hydroxykaurene (28) in G. fujikuroi was performed under conditions used for that of ent$15 \alpha$-hydroxykaurenoic acid except chlorocholine (CCC) was used as GA biosynthesis inhibitor. After 5 days, the acidic metabolites

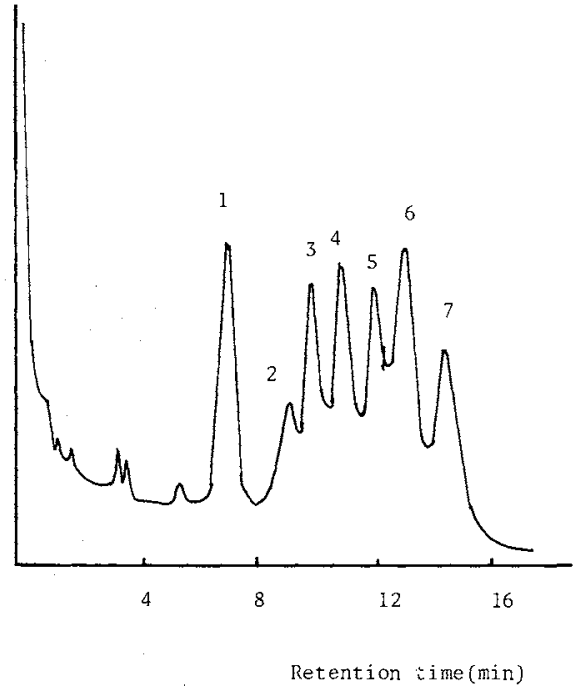

FIG. 8. Gas Chromatogram of the Methyl Esters of the Acidic Metabolites from ent-12 $\beta$-Hydroxykaur-16-ene.

$3 \%$ OV-1 on $100 \sim 120$ mesh Gaschrom Q; $\mathrm{N}_{2} 40 \mathrm{ml} / \mathrm{min}$, $210^{\circ} \mathrm{C}$.

were extracted, and their methyl esters were analyzed by GC-MS. As shown in Fig. 8 , the main metabolites (peaks, 1, 2, 3, 6, and 7) were tentatively assigned $12 \alpha$-hydroxy $\mathrm{GA}_{12}(\mathbf{3 0})$, $12 \alpha$-hydroxy $\mathrm{GA}_{25}$ (31), ent-7 $\alpha, 12 \beta$-dihy-

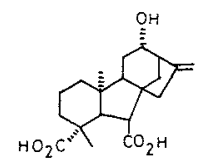

(30)

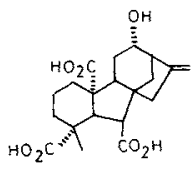

(31)

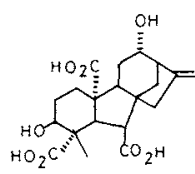

(32) droxykaurenoic acid, ent- $6 \alpha, 7 \alpha, 12 \beta$-trihydroxykaurenoic acid and $\mathrm{GA}_{39}$ (32) which has been found in immature seds of Cucurbitae pepo. ${ }^{14)}$

Since ent-kaurenoic acid and ent-kaurene are reasonably available from the heads of sunflower ${ }^{15)}$ and the leaves of Cryptomeria japonica, respectively, the microbial transformations of their derivatives provide a practical route to inaccessible plant gibberellins and their analogues. Studies on the specific biological activities of $\mathrm{GA}_{45}$ and related 15 $\beta$-hydroxyl GAs are now in progress. 


\section{EXPERIMENTAL}

Melting points were determined with a Kofler hot-stage apparatus. IR spectra were recorded with a JASCO A-III spectrometer, ${ }^{1} \mathrm{H}$ NMR spectra with a JEOL JNM-MH$100(100 \mathrm{MHz})$ spectrometer (tetramethylsilane as internal standard): Mass spectra and GC-MS were measured with a JEOL JMS-D 100 spectrometer equipped with a JEOL JGC-20K gas chromatography. Gas chromatographic conditions were as follows: column, $1 \mathrm{~m} \times 2 \mathrm{~mm}$ glass column packed with $3 \%$ OV-1 on Gas Chrom Q; oven temperature, $230^{\circ} \mathrm{C}$; Carrier gas, $\mathrm{He}, c a .40 \mathrm{ml} / \mathrm{min}$. Methylation was carried out by treatment with ethereal diazomethane and trimethylsilylation was with TMS-HT reagent (Tokyo Kasei).

Optical rotations were measured with JEOL DIP-4 polarimeter. Silica gel $60 \mathrm{PF}_{254}$ (Merk) was used for analytical and preparative TLC. Mallinckrodt silica gel was used for column chromatography. HPLC were performed with Hitachi 635 .

Synthesis of ent-15 $\alpha$-hydroxykaurenoic acid (8).

Isomerization of ent-kaur-16-en-19-oic acid methyl ester (2). ent-Kaurenoic acid methyl ester $(3.5 \mathrm{~g})$, dissolved in glacial acetic acid $(200 \mathrm{ml})$, was refluxed for $5 \mathrm{hr}$. The reaction mixture was then poured into water and extracted with ethyl acetate. The extract was washed with saturated aqueous sodium hydrogen carbonate, water and brine, dried over $\mathrm{Na}_{2} \mathrm{SO}_{4}$, and evaporated to afford an inseparable mixture of the starting material and ent-kaur15-en-19-oic acid methyl ester (3) $(1: 2.6)$. The ratio of 2 and 3 was determined by NMR and GC analysis. NMR $\left(\mathrm{CDCl}_{3}\right) \delta: 0.80(3 \mathrm{H}, \mathrm{s}), 0.84(3 \mathrm{H}, \mathrm{s}), 1.01(3 \mathrm{H}, \mathrm{s}), 1.71$ $(2.2 \mathrm{H}, \mathrm{s}), 4.7 .4(0.6 \mathrm{H}, \mathrm{bs})$ and $5.08(0.7 \mathrm{H}, \mathrm{bs})$.

Photo-sensitized oxygenation and reduction of the mixture of 2 and 3. A mixture of 2 and $3(3.2 \mathrm{~g})$ and $45 \mathrm{mg}$ of hematoporphyrin was dissolved in $42 \mathrm{ml}$ of dry pyridine, and oxygen was passed through the solution under irradiation with fluorescent tubes $(20 \mathrm{~W} \times 4)$. After $69 \mathrm{hr}$, the reaction mixture was concentrated in vacuo below $40^{\circ} \mathrm{C}$. To the residue was added a solution of $\mathrm{KI}(18 \mathrm{~g})$ in $140 \mathrm{ml}$ of ethanol and $3 \mathrm{ml}$ of acetic acid, and the mixture was kept at room temperature overnight. After decomposition of iodine with $\mathrm{Na}_{2} \mathrm{~S}_{2} \mathrm{O}_{3}$ solution, the solvent was evaporated to leave an oilly residue, which was suspended in $300 \mathrm{ml}$ of water, and extracted with ethyl acetate. The extract was washed with water and brine, and dried over $\mathrm{Na}_{2} \mathrm{SO}_{4}$.

Removal of solvent gave an oil $(3.3 \mathrm{~g})$, which was then chromatographed on a column of silica gel $(150 \mathrm{~g})$ in $n$ hexane containing increasing amounts of ethyl acetate. Elution with ethyl acetate $n$-hexane $(2: 8)$ gave two products, ent-15 $\beta$-hydroxykaurenoic acid methyl ester (4) $(1.36 \mathrm{~g})$ and ent-17-hydroxykaur-15-en-19-oic acid methyl ester (5) (507 mg).

4. $\mathrm{mp} 102 \sim 103^{\circ} \mathrm{C} .[\alpha]_{\mathrm{D}}^{34},-114^{\circ}(c=0.39$, EtOH $)$. MS $(m / z): 332\left(\mathrm{M}^{+}\right), 317\left(\mathrm{M}^{+}-\mathrm{CH}_{3}\right), 314\left(\mathrm{M}^{+}-\mathrm{H}_{2} \mathrm{O}\right), 299$, 273, 255, 239 and 207. IR $v_{\max }^{\mathrm{KBr}} \mathrm{cm}^{-1}: 3300$ and 1720 . NMR $\left(\mathrm{CDCl}_{3}\right) \delta: 0.86(3 \mathrm{H}, \mathrm{s}), 1.21(3 \mathrm{H}, \mathrm{s}), 2.75(1 \mathrm{H}, \mathrm{m})$, $3.66(3 \mathrm{H}, \mathrm{s}), 3.83(1 \mathrm{H}, \mathrm{bs}), 5.10(1 \mathrm{H}, \mathrm{s})$, and $5.23(1 \mathrm{H}, \mathrm{s})$.

5, mp $114 \sim 116^{\circ} \mathrm{C} .[\alpha]_{\mathrm{D}}^{30}-59.2^{\circ}\left(c=0.90, \mathrm{CHCl}_{3}\right)$. MS $(\mathrm{m} / \mathrm{z}): 332\left(\mathrm{M}^{+}\right), 317\left(\mathrm{M}^{+}-\mathrm{CH}_{3}\right), 314\left(\mathrm{M}^{+}-\mathrm{H}_{2} \mathrm{O}\right), 299$, 273, 255, 239, and 207. IR $v_{\max }^{\mathrm{KBr}} \mathrm{cm}^{-1}: 3300$ and 1720 . NMR $\left(\mathrm{CDCl}_{3}\right) \delta: 0.96(3 \mathrm{H}, \mathrm{s}), 1.97(3 \mathrm{H}, \mathrm{s}), 2.51(1 \mathrm{H}, \mathrm{m})$, $3.61(3 \mathrm{H}, \mathrm{s}), 4.16(2 \mathrm{H}, \mathrm{s})$ and $5.32(1 \mathrm{H}, \mathrm{bs})$. Anal. Found: C, 74.71; $\mathrm{H}, 9.57$. Calcd for $\mathrm{C}_{21} \mathrm{H}_{32} \mathrm{O}_{3}: \mathrm{C}, 75.85 ; \mathrm{H}, 9.70$.

Manganese dioxide oxidation of 4. Methyl ester (4) $(1.0 \mathrm{~g})$ dissolved in dry $\mathrm{CH}_{2} \mathrm{Cl}_{2}(50 \mathrm{ml})$ was stirred with active manganese dioxide $(10 \mathrm{~g})$ for $3 \mathrm{hr}$. The reaction mixture was then filtered and washed with $\mathrm{CH}_{2} \mathrm{Cl}_{2}$, and the filtrate was evaporated under reduced pressure to give ent-15-oxokaurenoic acid methyl ester (6) $(850 \mathrm{mg}$ ). Recrystallization from methanol gave 6 as colorless prisms, mp $148 \sim 149^{\circ} \mathrm{C}$. $[\alpha]_{\mathrm{D}}^{34}-189^{\circ}(c=0.38$, EtOH). MS $(m / z): 330\left(\mathrm{M}^{+}\right), 315\left(\mathrm{M}^{+}-\mathrm{CH}_{3}\right), 271,270,255$ and 237. IR $v_{\max }^{\mathrm{KBr}} \mathrm{cm}^{-1}: 1720,1640,1160$ and 940. NMR $\left(\mathrm{CDCl}_{3}\right) \delta$ : $0.93(3 \mathrm{H}, \mathrm{s}), 1.21(3 \mathrm{H}, \mathrm{s}), 3.03(1 \mathrm{H}, \mathrm{m}), 3.65(3 \mathrm{H}, \mathrm{s}), 5.24$ $(1 \mathrm{H}, \mathrm{s})$ and $5.93(1 \mathrm{H}, \mathrm{s})$. Anal. Found: C, 76.09; H, 9:11. Calcd for $\mathrm{C}_{21} \mathrm{H}_{30} \mathrm{O}_{3}$ : C, 76.31; H, 9.15.

Sodium borohydride reduction of ent-15-oxokaurenoic acid methyl ester (6). A solution of $6(640 \mathrm{mg})$ in $60 \mathrm{ml}$ of methanol was treated with $500 \mathrm{mg}$ of sodium borohydride at $-20^{\circ} \mathrm{C}$ for $3 \mathrm{hr}$. The reaction mixture was then poured into water and extracted with ethyl acetate. The extract was washed with brine, and dried over $\mathrm{Na}_{2} \mathrm{SO}_{4}$. The solution, on evaporation, gave $612 \mathrm{mg}$ of ent-15 $\alpha$ hydroxykaurenoic acid methyl ester (7), which was recrystallized from methanol.

7, mp $169 \sim 171^{\circ} \mathrm{C} .[\alpha]_{\mathrm{D}}^{30}-91.0\left(c=0.93, \mathrm{CHCl}_{3}\right)$. MS $(m / z): 332\left(\mathrm{M}^{+}\right), 317\left(\mathrm{M}^{+}-\mathrm{CH}_{3}\right), 314\left(\mathrm{M}^{+}-\mathrm{H}_{2} \mathrm{O}\right), 299$, 274, 257, 255 and 239. IR $v_{\max }^{\mathrm{KBr}} \mathrm{cm}^{-1}: 3535,3080,1700$, 1660. NMR $\left(\mathrm{CDCl}_{3}\right)$ \&: $0.87(3 \mathrm{H}, \mathrm{s}), 1.19(3 \mathrm{H}, \mathrm{s}), 2.66$ $(1 \mathrm{H}, \mathrm{m}), 3.66(3 \mathrm{H}, \mathrm{s}), 3.76(1 \mathrm{H}, \mathrm{bs}), 4.96(1 \mathrm{H}, \mathrm{bd}$, $J=2.3 \mathrm{~Hz})$ and $5.10(1 \mathrm{H}, \mathrm{bs})$. Anal. Found: C, $75.39 ; \mathrm{H}$, 9.63. Calcd for $\mathrm{C}_{21} \mathrm{H}_{32} \mathrm{O}_{3}: \mathrm{C}, 75.85 ; \mathrm{H}, 9.70$, identical in optical rotation, and IR and NMR spectra with authentic material. ${ }^{7}$

GC-MS analysis of this material showed it is a mixture of 7 and its dihydroderivative $(96: 4)$.

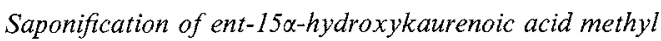
ester (7). A solution of $7(500 \mathrm{mg})$ and potassium hydroxide $(7.5 \mathrm{~g})$ in $50 \mathrm{ml}$ of ethylene glycol was reffuxed for $4.5 \mathrm{hr}$. The solution was then diluted with water $(150 \mathrm{ml})$, washed with ether to remove neutral materials, acidified with cold conc. $\mathrm{HCl}$, and extracted with ether. The ether extract was washed with brine and dried over $\mathrm{Na}_{2} \mathrm{SO}_{4}$. The solution, on evaporation and recrystallization from aqueous methanol, gave ent-15 -hydroxykaurenoic acid (8) as colorless prisms, mp $115 \sim 117^{\circ} \mathrm{C} .[\alpha]_{\mathrm{D}}^{34}-94.8^{\circ}$ $(c=0.66, \mathrm{EtOH})$. MS $(m / z) ; 318\left(\mathrm{M}^{+}\right), 303\left(\mathrm{M}^{+}-\mathrm{CH}_{3}\right)$, 
$300\left(\mathrm{M}^{+}-\mathrm{H}_{2} \mathrm{O}\right), 285,260,257,245,243,239$ and 189. IR $v_{\max }^{\mathrm{KBr}} \mathrm{cm}^{-1}: 3400,3070$, and 1690. NMR $\left(\mathrm{CDCl}_{3}\right) \delta$ : $1.00(3 \mathrm{H}, \mathrm{s}), 1.27(3 \mathrm{H}, \mathrm{s}), 2.66(1 \mathrm{H}, \mathrm{m}), 3.76(1 \mathrm{H}, \mathrm{bs}), 4.96$ $(1 \mathrm{H}, \mathrm{bs})$ and $5.10(1 \mathrm{H}, \mathrm{bs})$. Anal. Found: C, 74.69; H,9.45. Calcd. for $\mathrm{C}_{20} \mathrm{H}_{30} \mathrm{O}_{3}: \mathrm{C}, 74.44 ; \mathrm{H}, 9.50$.

Microbial transformation of ent-15 $\alpha$-hydroxykaurenoic acid (8). In a time coarse incubation, the artificial substrate, $8(60 \mathrm{mg})$ and washed mycelium obtained from $200 \mathrm{ml}$ of the preculture of $G$. fujikuroi were added to a Sakaguchi flask containing $110 \mathrm{ml}$ of $\mathrm{N}-0 \%$ ICI medium ${ }^{3)}$ and $10 \mathrm{ml}$ of $8 \%$ Tween 20 , and incubated at $30^{\circ} \mathrm{C}$ on a reciprocal shaker. Small portions of the suspension ( $\mathrm{ca}$. $10 \mathrm{ml}$ ) were removed in the 1 st, $3 \mathrm{rd}, 5$ th and 7 th days and filtered, and their acidic metabolites were extracted with ethyl acetate.

After evaporation these extracts were methylated with diazomethane and subjected to GC-MS, which showed four main peaks corresponding to the methyl esters of A-I, A-III, A-IV and ent-7 $\alpha, 15 \alpha$-dihydroxykaurenoic acid (see Fig. 1).

In the large scale culture, $1.5 \mathrm{~g}$ of $\mathbf{8}$ was distributed between Sakaguchi flasks $(25 \times 500 \mathrm{ml})$. Wet mycelium of G. fujikuroi, resuspended in $110 \mathrm{ml}$ of $\mathrm{N}-0 \%$ ICI medium and $10 \mathrm{ml}$ of $8 \%$ Tween 20 containing $9 \mathrm{mg}$ of $1-n$ decylimidazole was added to each of the flasks. After 7 days incubation the culture filtrate was extracted with ethyl acetate ( 3 liters) at $\mathrm{pH} 2.0$. The extract concentrated to $c a .500 \mathrm{ml}$ was extracted with $5 \% \mathrm{NaHCO}_{3}$ twice. The aqueous solution was acidified to $\mathrm{pH} 2.0$, and extracted with ethyl acetate ( 1 liter) twice. The ethyl acetate extract, on evaporation, gave $947 \mathrm{mg}$ of gummy acidic material. The acidic metabolites was fractioned into 7 fractions with preparative TLC on silica gel developed with $\mathrm{CHCl}_{3}$ EtOAc-AcOH $(10: 10: 1)$. Each fraction was then subjected to HPLC on Lichrosorb RP-18 $(8 \times 250 \mathrm{~mm})$ with $\mathrm{CH}_{3} \mathrm{CN}-\mathrm{MeOH}-1 \% \mathrm{H}_{3} \mathrm{PO}_{4}(40: 10: 50)$, and the eluates were monitored by RI and UV detectors. The eluate collected was neutralized to $\mathrm{pH} 6.0$, and the solvent were evaporated. The residue was acidified to $\mathrm{pH} 2.0$, and extracted with ethyl acetate.

From HPLC of the fraction II, A-I (105 mg), A-II $(28 \mathrm{mg}), \mathrm{A}-\mathrm{III}(46 \mathrm{mg}), \mathrm{A}-\mathrm{IV}(104 \mathrm{mg})$ and A-V $(16 \mathrm{mg})$ were obtained. HPLC of the other fraction (III to VII) gave the metabolites, A-VI (35 mg), A-VII ( $47 \mathrm{mg})$, A-VIII $(2.9 \mathrm{mg})$ and A-IX (14 mg), as described in Fig. 2.

$A-I, \quad 15 \beta-H y d r o x y \quad G A_{24}(9)$. A-I was isolated as a powder, $[\alpha]_{\mathrm{D}}^{32}-81^{\circ}(c=0.40, \mathrm{MeOH})$. Methyl ester, (Found: $\mathrm{M}^{+}, 390.2040 . \mathrm{C}_{22} \mathrm{H}_{30} \mathrm{O}_{6}$ requires 390.2042), IR $v_{\max }^{\mathrm{CHCl}_{3}} \mathrm{~cm}^{-1}: 3530,1720,1715,1660$ and 910. NMR $\left(\mathrm{CDCl}_{3}\right) \delta: 1.10\left(3 \mathrm{H}, \mathrm{s}, 18-\mathrm{H}_{3}\right), 2.13(1 \mathrm{H}, \mathrm{d}, J=13.2 \mathrm{~Hz}, 5-$ $\mathrm{H}), 3.42\left(1 \mathrm{H}, \mathrm{d}, J=3.7 \mathrm{~Hz},-\mathrm{OH}\right.$, exchanged with $\left.\mathrm{D}_{2} \mathrm{O}\right)$, $3.63\left(3 \mathrm{H}, \mathrm{s}, \mathrm{CO}_{2} \mathrm{CH}_{3}\right), 3.79\left(3 \mathrm{H}, \mathrm{s}, \mathrm{CO}_{2} \mathrm{CH}_{3}\right), 3.96(1 \mathrm{H}, \mathrm{d}$, $J=13.2 \mathrm{~Hz}, 6-\mathrm{H}), 3.97(1 \mathrm{H}$, bd, $J=3.7 \mathrm{~Hz}$, reduced to a sharp triplet, $J=1 \mathrm{~Hz}$, in addition of $\left.\mathrm{D}_{2} \mathrm{O}, 15-\mathrm{H}\right), 5.04$ and 5.14 (both bs, $\left.17-\mathrm{H}_{2}\right)$ and $9.63(1 \mathrm{H}, \mathrm{s},-\mathrm{CHO})$. MS $(\mathrm{m} / \mathrm{z})$ :
$390\left(\mathrm{M}^{+}, 6 \%\right), 362(4), 358(17), 344(4), 340(82), 330(61)$, $328(16), 312(51), 302(60), 298(28), 284(97), 270(100)$, $242(51)$ and 225 (58). MeTMSi derivative: MS ( $m / z): 462$ $\left(\mathrm{M}^{+}, 16 \%\right), 447(36), 434(17), 430(26), 402(79), 374(40)$, $341(28), 312(59), 284(100), 225(52)$ and $156(100)$

$A-I I(\mathbf{1 0})$ was isolated as its methyl ester. Methyl ester of $A-I I$, (Found: $\mathrm{M}^{+}-28364.2261 . \mathrm{C}_{21} \mathrm{H}_{32} \mathrm{O}_{5}$ requires

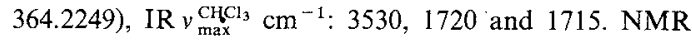
$\left(\mathrm{CDCl}_{3}\right) \delta: 0.86\left(3 \mathrm{H}, \mathrm{d}, J=7.3 \mathrm{~Hz}, 17-\mathrm{H}_{3}\right), 1.08(3 \mathrm{H}, \mathrm{s}, 18-$ $\left.\mathrm{H}_{3}\right), 2.08(1 \mathrm{H}, \mathrm{d}, J=12.7 \mathrm{~Hz}, 5-\mathrm{H}), 3.63$ and 3.77 (both $\left.3 \mathrm{H}, \mathrm{s}, 2 \times \mathrm{CO}_{2} \mathrm{CH}_{3}\right), 3.89(1 \mathrm{H}, \mathrm{d}, J=12.9 \mathrm{~Hz}, 6-\mathrm{H})$, and $9.63(1 \mathrm{H}, \mathrm{s},-\mathrm{CHO})$. MS (m/z): $392\left(\mathrm{M}^{+}, 2 \%\right), 364(2), 360$ (5), $346(5), 342$ (5), 332 (20), 328 (5), 314 (30), 304 (22), 301 (11), 300 (8), 286 (49), 271 (25), 255 (16), 245 (53), 227 (46), 178 (100) and 150 (37). MeTMSi derivative, MS (m/z): $464\left(\mathrm{M}^{+}, 4 \%\right), 449(20), 432(13), 404(22)$, 374 (20), 342 (93), 314 (67), $310(27), 286(100), 285(82)$, $255(38), 227(42)$ and $130(22)$.

A-III (11) was recrystallized from ethyl acetate. Colorless prisms, mp $204 \sim 205^{\circ} \mathrm{C}$. $[\alpha]_{\mathrm{D}}^{33} \pm 40.0(c=0.21$, $\mathrm{MeOH}$ ). Methyl ester (Found: $\mathrm{M}^{+}$346.1786. $\mathrm{C}_{20} \mathrm{H}_{26} \mathrm{O}_{5}$

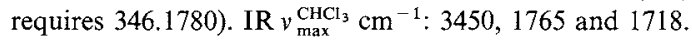
NMR $\left(\mathrm{CDCl}_{3}\right) \delta: 1.08\left(3 \mathrm{H}, \mathrm{s}, 18-\mathrm{H}_{3}\right), 2.45(1 \mathrm{H}, \mathrm{d}$, $J=10.7 \mathrm{~Hz}, 5-\mathrm{H}), 2.75(1 \mathrm{H}, \mathrm{d}, J=10.7 \mathrm{~Hz}, 6-\mathrm{H}), 3.76(3 \mathrm{H}$, $\left.\mathrm{s}, \mathrm{CO}_{2} \mathrm{CH}_{3}\right), 3.93(1 \mathrm{H}, \mathrm{b}, 15-\mathrm{H})$, and $5.08\left(2 \mathrm{H}, \mathrm{m}, 17-\mathrm{H}_{2}\right)$. MS (m/z): $346\left(\mathrm{M}^{+}, 45 \%\right), 328(1), 314(100), 300(7), 286$ (23), 284 (20), 268 (20), 242 (35), 241 (30), 225 (28), 214 (27), 213 (27), and 185 (27). MeTMSi derivative: MS $(\mathrm{m} / \mathrm{z}): 418\left(\mathrm{M}^{+}, 100 \%\right), 403(23), 386(5), 375(6), 372(7)$, 358 (43), 329 (9), 328 (9), 313 (8), 296 (6), 284 (18), 269 (22), $241(9), 225(18), 223(13)$ and $156(64)$.

$A-I V(12)$. Colorless prisms (from ethyl acetate), mp $265 \sim 267^{\circ} \mathrm{C} .[\alpha]_{\mathrm{D}}^{29}-66.7^{\circ}(c=0.12, \mathrm{MeOH})$. Methyl ester (Found: $\mathrm{M}^{+}$360.1931. $\mathrm{C}_{21} \mathrm{H}_{28} \mathrm{O}_{5}$ requires 360.1937). IR $v_{\max }^{\mathrm{CHCl}_{3}} \mathrm{~cm}^{-1}: 3530,1720,1660$ and $900 . \mathrm{NMR}\left(\mathrm{CDCl}_{3}\right)$ $\delta: 1.11\left(3 \mathrm{H}, \mathrm{s}, 18-\mathrm{H}_{3}\right), 2.11(1 \mathrm{H}, \mathrm{d}, J=12.9 \mathrm{~Hz}, 5-\mathrm{H}), 2.81$ $(1 \mathrm{H}, \mathrm{d}, J=12.9 \mathrm{~Hz}, 6-\mathrm{H}), 3.26(1 \mathrm{H}, \mathrm{d}, J=3.0,-\mathrm{OH}$, exchanged with $\left.\mathrm{D}_{2} \mathrm{O}\right), 3.78\left(3 \mathrm{H}, \mathrm{s}, \mathrm{CO}_{2} \mathrm{CH}_{3}\right), 3.88(1 \mathrm{H}$, bd, $J=3$, reduced to a sharp triplet, $J=1$ in addition of $\left.\mathrm{D}_{2} \mathrm{O}, 15-\mathrm{H}\right), 4.14(1 \mathrm{H}, \mathrm{d}, J=12.2)$ and $4.41(1 \mathrm{H}, \mathrm{d}$, $J=12.2)\left(20-\mathrm{H}_{2}\right)$, and $5.05(1 \mathrm{H}, \mathrm{bs})$ and $5.12(1 \mathrm{H}, \mathrm{bs})(17-$ $\left.\mathrm{H}_{2}\right)$. MS (m/z): $360\left(\mathrm{M}^{+}, 3 \%\right), 342(2), 329(27), 328(100)$, $314(3), 310(12), 300(27), 282(24), 271(10), 255(20), 254$ (19), 243 (13), 242 (13), 241 (12), 225 (14), 175 (12) and 159 (21). MeTMSi derivative: MS $(\mathrm{m} / \mathrm{z}): 432\left(\mathrm{M}^{+}, 29 \%\right), 417$ (24), 414 (1), 400 (18), 386 (4), 385 (5), 372 (16), 349 (9), 342 (5), 317 (4), 310 (27), 284 (14), 283 (14), 282 (19), 242 (13), $237(15), 225$ (13), 181 (13) and $156(100)$.

$A-V$ (13). Colorless prisms, mp $232 \sim 233^{\circ} \mathrm{C} .[\alpha]_{0}^{33}$ $-27.8(c=0.09, \mathrm{MeOH})$. Methyl ester (Found: $\mathbf{M}^{+}$ 348.1952. $\mathrm{C}_{20} \mathrm{H}_{28} \mathrm{O}_{5}$ requires 348.1936). IR $v_{\max }^{\mathrm{CHCl}_{3}} \mathrm{~cm}^{-1}$ : 3550,1765 and 1720. NMR $\left(\mathrm{CDCl}_{3}\right) \delta: 0.85(3 \mathrm{H}, \mathrm{d}$, $\left.J=7.3 \mathrm{~Hz}, 17-\mathrm{H}_{3}\right), 1.07\left(3 \mathrm{H}, \mathrm{s}, 18-\mathrm{H}_{3}\right), 2.39(1 \mathrm{H}, \mathrm{d}$, 
$J=10.7 \mathrm{~Hz}, 5-\mathrm{H}), 2.72(1 \mathrm{H}, \mathrm{d}, J=10.7 \mathrm{~Hz}, 6-\mathrm{H}), 3.63(1 \mathrm{H}$, $\mathrm{d}, J=10.5 \mathrm{~Hz}, 15-\mathrm{H})$, and $3.74\left(3 \mathrm{H}, \mathrm{s}, \mathrm{CO}_{2} \mathrm{CH}_{3}\right) . \mathrm{MS}$ $(\mathrm{m} / \mathrm{z}): 348\left(\mathrm{M}^{+}, 10 \%\right), 330(9), 316(73), 304(42), 302(26)$, $300(20), 289(42), 271(42), 257(95), 245$ (100), 243 (97), $230(63), 185(100)$ and 183 (63). MeTMSi derivative: MS $(\mathrm{m} / \mathrm{z}): 420\left(\mathrm{M}^{+}, 18 \%\right), 405(31), 388(17), 373(5), 360(10)$, $343(10), 330(79), 312(11), 298(60), 284(57), 270(69)$, $256(59)$ and $130(100)$.

Methyl ester of $A-V I$ (14). High MS (Found: $\mathrm{M}^{+}$ 420.2151. $\mathrm{C}_{23} \mathrm{H}_{32} \mathrm{O}_{7}$ requires 420.2148). IR $v_{\max }^{\mathrm{CHCl}_{3}} \mathrm{~cm}^{-1}$ : 3530 and 1722. NMR $\left(\mathrm{CDCl}_{3}\right) \delta: 1.10\left(3 \mathrm{H}, \mathrm{s}, 18-\mathrm{H}_{3}\right), 2.05$ $(1 \mathrm{H}, \mathrm{d}, J=12.9 \mathrm{~Hz}, 5-\mathrm{H}), 3.60\left(3 \mathrm{H}, \mathrm{s}, \mathrm{CO}_{2} \mathrm{CH}_{3}\right), 3.63(3 \mathrm{H}$, $\left.\mathrm{s}, \mathrm{CO}_{2} \mathrm{CH}_{3}\right), 3.78\left(3 \mathrm{H}, \mathrm{s}, \mathrm{CO}_{2} \mathrm{CH}_{3}\right), 3.89(1 \mathrm{H}, \mathrm{b}, 15-\mathrm{H})$, $3.95(1 \mathrm{H}, \mathrm{d}, J=12.7 \mathrm{~Hz}, 6-\mathrm{H}), 5.00(1 \mathrm{H}, \mathrm{bd}, J=2.7 \mathrm{~Hz})$ and $5.10(1 \mathrm{H}, \mathrm{bs})\left(17-\mathrm{H}_{2}\right)$. MS $(\mathrm{m} / \mathrm{z}): 420\left(\mathrm{M}^{+}, 3 \%\right), 388$ (16), $370(3), 360(20), 356(8), 328(100), 324(5), 311(13)$, $310(12), 300(75), 296(10), 283(22), 268(49)$, and 240 (42). MeTMSi derivative: MS (m/z): $492\left(\mathrm{M}^{+}, 10 \%\right), 473$ (20), $460(15), 432(100), 400(82), 372(85), 342(41), 313$ $(28), 311(36), 310(54), 283$ (54), $282(54), 250(18), 223$ (46), and $156(100)$.

A-VII (15). Colorless prisms, mp $234 \sim 235^{\circ} \mathrm{C}$. Methyl ester (Found: $\mathrm{M}^{+}$364.2270. $\mathrm{C}_{21} \mathrm{H}_{32} \mathrm{O}_{5}$ requires 364.2249). IR $v_{\max }^{\mathrm{CHCl}_{3}} \mathrm{~cm}^{-1} ; 3530,1700,1665$ and 900. $\operatorname{NMR}\left(\mathrm{CDCl}_{3}\right) \delta: 0.87\left(3 \mathrm{H}, \mathrm{s}, 20-\mathrm{H}_{3}\right), 1.41\left(3 \mathrm{H}, \mathrm{s}, 18-\mathrm{H}_{3}\right)$, $1.88(1 \mathrm{H}, \mathrm{d}, J=10.7 \mathrm{~Hz}, 5-\mathrm{H}), 3.69(1 \mathrm{H}, \mathrm{d}, J=2.2 \mathrm{~Hz}, 7-$ $\mathrm{H}), 3.74\left(3 \mathrm{H}, \mathrm{s}, \mathrm{CO}_{2} \mathrm{CH}_{3}\right), 4.23(1 \mathrm{H}, \mathrm{dd}, J=10.7,2.4 \mathrm{~Hz}$, $6-\mathrm{H}), 4.33(1 \mathrm{H}, \mathrm{d}, J=2.4 \mathrm{~Hz}, 15-\mathrm{H}), 4.97(1 \mathrm{H}, \mathrm{bd}$, $J=2.9 \mathrm{~Hz})$ and $5.14(1 \mathrm{H}, \mathrm{bs})\left(17-\mathrm{H}_{2}\right)$.

Methyl ester of $A-V I I I(16)$. High MS ( $m / z)$ : (Found: $\mathrm{M}^{+}$362.1710. $\mathrm{C}_{20} \mathrm{H}_{26} \mathrm{O}_{6}$ requires 362.1729. IR $v_{\max }^{\mathrm{CHCl}_{3}}$ $\mathrm{cm}^{-1}: 3520,1765$ and 1720 . NMR $\left(\mathrm{CDCl}_{3}\right) \delta: 1.15(3 \mathrm{H}, \mathrm{s}$, $\left.18-\mathrm{H}_{3}\right), 2.73(1 \mathrm{H}, \mathrm{d}, J=11.2 \mathrm{~Hz}, 6-\mathrm{H}), 3.09(1 \mathrm{H}, \mathrm{d}$, $J=11.0 \mathrm{~Hz}, 5-\mathrm{H}), 3.76\left(3 \mathrm{H}, \mathrm{s}, \mathrm{CO}_{2} \mathrm{CH}_{3}\right), 3.83(1 \mathrm{H}, \mathrm{bs}, 1 \alpha-$ $\mathrm{H}$ or $3 \alpha-\mathrm{H}), 3.96(1 \mathrm{H}, \mathrm{b}, 15-\mathrm{H})$, and $5.11\left(2 \mathrm{H}, \mathrm{bs}, 17-\mathrm{H}_{2}\right)$. MS $(m / z): 362\left(\mathrm{M}^{+}, 6 \%\right), 344(5), 331(25), 330(100), 316$ (5), $312(7), 302(7), 284(20), 255(15), 239(13)$, and 148 (20). MeTMSi derivative: MS $(\mathrm{m} / \mathrm{z}): 506\left(\mathrm{M}^{+}, 6 \%\right), 491$ (32), 474 (4), $446(23), 416(15), 384(6), 377(8), 372$ (7), $356(6), 287(25), 282(15), 223(10), 156(38)$ and $129(11)$.

Methyl ester of $A-I X(\mathbf{1 7})$ : High MS $(\mathrm{m} / \mathrm{z})$ : (Found: $\mathrm{M}^{+}$ 436.2121. $\mathrm{C}_{23} \mathrm{H}_{32} \mathrm{O}_{8}$ requires 436.2097). IR $v_{\max }^{\mathrm{CHCl}_{3}} \mathrm{~cm}^{-1}$ : 3520 and 1720 . NMR $\left(\mathrm{CDCl}_{3}\right) \delta: 1.20\left(3 \mathrm{H}, \mathrm{s}, 18-\mathrm{H}_{3}\right), 2.51$ $(1 \mathrm{H}, \mathrm{d}, J=12.9 \mathrm{~Hz}, 5-\mathrm{H}), 3.60\left(3 \mathrm{H}, \mathrm{s}, \mathrm{CO}_{2} \mathrm{CH}_{3}\right), 3.65(3 \mathrm{H}$, $\left.\mathrm{s}, \mathrm{CO}_{2} \mathrm{CH}_{3}\right), 3.78\left(3 \mathrm{H}, \mathrm{s}, \mathrm{CO}_{2} \mathrm{CH}_{3}\right), 3.90(1 \mathrm{H}, \mathrm{bs}, 15-\mathrm{H})$, $3.96(1 \mathrm{H}, \mathrm{d}, J=12.7 \mathrm{~Hz}, 6-\mathrm{H}), 5.02(1 \mathrm{H}, \mathrm{bs})$ and $5.10(1 \mathrm{H}$, bs) $\left(17-\mathrm{H}_{2}\right) . \mathrm{MS}(\mathrm{m} / \mathrm{z}): 436\left(\mathrm{M}^{+}, 12 \%\right), 404(42), 386(9)$, $376(49), 374(52), 372(39), 358(19), 344$ (100), $326(36)$, $316(57), 298(46), 284(36), 270(31), 239(32), 176(29)$ and 149 (39). MeTMSi derivative: $\mathrm{MS}(\mathrm{m} / \mathrm{z})$ : $586\left(\mathrm{M}^{+}, 54 \%\right)$, $565(63), 550(39), 548(27), 524$ (36), 520 (93), 479 (37), $478(51), 460(44), 430(67), 419(20), 399(41), 398(32)$, $371(41), 370(42), 156(100)$ and $129(98)$.
Synthesis of ent-12B-hydroxykaur-16-ene (28).

Hydroboration-oxidation of the acetate (22). The acetate (22) (860 mg), which was prepared from ent-kaurene (19) according to McAlees and McCrindle, ${ }^{16)}$ was dissolved in $64 \mathrm{ml}$ of diglyme and treated with $608 \mathrm{mg}$ of sodium borohydride and $2.6 \mathrm{ml}$ of borontrifluoride etherate for $2 \mathrm{hr}$. To the ice-cooled reaction mixture was added $6.4 \mathrm{ml}$ of $10 \% \mathrm{NaOH}$ in $30 \%$ aqueous ethanol and $12.8 \mathrm{ml}$ of $30 \% \mathrm{H}_{2} \mathrm{O}_{2}$, and stirred at room temperature overnight. The reaction mixture was then poured into $400 \mathrm{ml}$ of water, and extracted with $500 \mathrm{ml}$ of ethyl acetate. The extract was washed with $250 \mathrm{ml}$ of brine and dried over $\mathrm{Na}_{2} \mathrm{SO}_{4}$.

The solution, on evaporation and recrystallization from ethanol, gave $603 \mathrm{mg}$ of diol (23) as colorless needles, $\mathrm{mp}$ $222 \sim 224^{\circ} \mathrm{C}$. MS $(\mathrm{m} / \mathrm{z}): 306\left(\mathrm{M}^{+}\right), 291\left(\mathrm{M}^{+}-\mathrm{CH}_{3}\right), 288$ $\left(\mathrm{M}^{+}-\mathrm{H}_{2} \mathrm{O}\right), 273,254,203$. IR $v_{\max }^{\mathrm{KBr}} \mathrm{cm}^{-1}: 3280$

Monotosylation of the diol (23). $520 \mathrm{mg}$ of diol (23) was treated with $17 \mathrm{ml}$ of pyridine and $391 \mathrm{mg}$ of tosyl chloride at $4^{\circ} \mathrm{C}$ for $20 \mathrm{hr}$. The reaction mixture was poured into water $(400 \mathrm{ml})$, and extracted with $300 \mathrm{ml}$ of ethyl acetate twice. The combined extracts were washed with $5 \% \mathrm{HCl}$, $5 \% \mathrm{NaHCO}_{3}$ and brine, and dried over $\mathrm{Na}_{2} \mathrm{SO}_{4}$. The solution, on evaporation, gave $694 \mathrm{mg}$ of an oilly material, which was purified by preparative TLC with $40 \%$ ethyl acetate in $n$-hexane. Recrystallization from methanol and ethyl acetate gave $491 \mathrm{mg}$ of monotosylate (24) as colorless prisms, mp $145 \sim 148^{\circ} \mathrm{C}$. MS $(m / z): 460\left(\mathrm{M}^{+}\right), 445$ $\left(\mathrm{M}^{+}-\mathrm{CH}_{3}\right), 442\left(\mathrm{M}^{+}-\mathrm{H}_{2} \mathrm{O}\right), 305,289,270,255 . \mathrm{IR} v_{\max }^{\mathrm{KBr}}$ $\mathrm{cm}^{-1}: 3500$ and 1600. NMR $\left(\mathrm{CDCl}_{3}\right) \delta: 0.79(3 \mathrm{H}, \mathrm{s}), 0.83$ $(3 \mathrm{H}), \mathrm{s}), 1.14(3 \mathrm{H}, \mathrm{s}), 2.42(3 \mathrm{H}, \mathrm{s}), 3.72(1 \mathrm{H}, \mathrm{m}, 12-\mathrm{H}), 3.98$ $\left(2 \mathrm{H}, \mathrm{d}, J=8 \mathrm{~Hz}, 17-\mathrm{H}_{2}\right), 7.24(2 \mathrm{H}, \mathrm{d}, J=8 \mathrm{~Hz})$ and 7.70 $(2 \mathrm{H}, \mathrm{d}, J=8 \mathrm{~Hz})$.

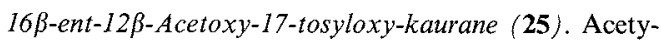
lation of $24(486 \mathrm{mg})$ with acetic anhydride $(6 \mathrm{ml})$ and pyridine $(6 \mathrm{ml})$ and usual work-up gave $600 \mathrm{mg}$ of the acetate (25) as an oily material, MS ( $\mathrm{m} / \mathrm{z}): 444\left(\mathrm{M}^{+}-60\right)$, 429, 369, 367, 289, 272 and 204. IR $v_{\max }{ }^{\mathrm{CHCl}_{3}} \mathrm{~cm}^{-1}: 1735$ and 1580. NMR $\left(\mathrm{CDCl}_{3}\right) \delta: 0.80(3 \mathrm{H}, \mathrm{s}), 0.85(3 \mathrm{H}, \mathrm{s}), 1.05$ $(3 \mathrm{H}, \mathrm{s}), 2.00\left(3 \mathrm{H}, \mathrm{s}, \mathrm{OCO}-\mathrm{CH}_{3}\right), 2.42(3 \mathrm{H}, \mathrm{s}), 4.01(2 \mathrm{H}, \mathrm{d}$, $J=8 \mathrm{~Hz}), 4.67(1 \mathrm{H}, \mathrm{m}, 12-\mathrm{H}), 7.26(2 \mathrm{H}, \mathrm{d}, J=8 \mathrm{~Hz})$ and $7.72(2 \mathrm{H}, \mathrm{d}, J=8 \mathrm{~Hz})$.

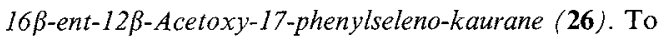
a solution of phenylselenide anions generated from sodium borohydride $(175 \mathrm{mg})$ and diphenyldiselenide $(713 \mathrm{mg})$ in $9 \mathrm{ml}$ of dimethylformamide under argon at $0^{\circ} \mathrm{C}$ was added dropwise $591 \mathrm{mg}$ of the acetate (25) in $4.5 \mathrm{ml}$ of dimethylformamide.

The reaction mixture warmed to $40^{\circ} \mathrm{C}$ was stirred for $4 \mathrm{hr}$, and poured into ice-water $(400 \mathrm{ml})$ and extracted with ethyl acetate. The extract was washed with brine $(300 \mathrm{ml})$ and dried over $\mathrm{Na}_{2} \mathrm{SO}_{4}$. Removal of the solvent, followed by preparative TLC with $20 \%$ ethyl acetate in $n$ hexane afforded $415 \mathrm{mg}$ of phenylseleno compound (26) as 
a colorless solid, MS $(m / z): 488\left(\mathrm{M}^{+}\right), 428\left(\mathrm{M}^{+}-60\right), 351$, 289, 271, and 230). IR $\nu_{\max }^{\mathrm{KBr}} \mathrm{cm}^{-1}: 1730$ and 1600. NMR $\left(\mathrm{CDCl}_{3}\right) \delta: 0.81(3 \mathrm{H}, \mathrm{s}), 0.85(3 \mathrm{H}, \mathrm{s}), 1.07(3 \mathrm{H}, \mathrm{s}), 2.02$ $\left(3 \mathrm{H}, \mathrm{s}, \mathrm{OCO}-\mathrm{CH}_{3}\right), 2.96\left(2 \mathrm{H}, \mathrm{t}, J=8,17-\mathrm{H}_{2}\right), 4.92(1 \mathrm{H}, \mathrm{m}$, $12-\mathrm{H}), 7.17(3 \mathrm{H}, \mathrm{m})$ and $7.41(2 \mathrm{H}, \mathrm{m})$.

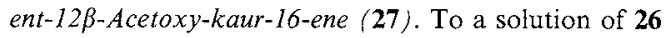
$(408 \mathrm{mg})$ in $\mathrm{THF}(20 \mathrm{ml})$ cooled to $0^{\circ} \mathrm{C}$ was added $30 \%$ $\mathrm{H}_{2} \mathrm{O}_{2}(1.2 \mathrm{ml})$. The reaction mixture was stirred for $30 \mathrm{~min}$ at $0^{\circ} \mathrm{C}$, and kept at room temperature overnight. The mixture was poured into water $(300 \mathrm{ml})$, and extracted with ethyl acetate $(250 \mathrm{ml})$ twice. The extract was washed with brine $(300 \mathrm{ml})$ and dried over $\mathrm{Na}_{2} \mathrm{SO}_{4}$. Preparative TLC of the crude material afforded $247 \mathrm{mg}$ of the acetate (27) as a colorless solid. MS $(\mathrm{m} / \mathrm{z}): 330\left(\mathrm{M}^{+}\right), 315$ $\left(\mathrm{M}^{+}-\mathrm{CH}_{3}\right), 271,270,256$ and $227 . \mathrm{IR} v_{\max }^{\mathrm{KBr}} \mathrm{cm}^{-1}: 1735$. NMR $\left(\mathrm{CDCl}_{3}\right) \delta: 0.82(3 \mathrm{H}, \mathrm{s}), 0.86(3 \mathrm{H}, \mathrm{s}), 1.10(3 \mathrm{H}, \mathrm{s})$, $2.02\left(3 \mathrm{H}, \mathrm{s}, \mathrm{OCO}-\mathrm{CH}_{3}\right), 2.71(1 \mathrm{H}, \mathrm{m}, 13-\mathrm{H}), 4.68(1 \mathrm{H}, \mathrm{m}$, $12-\mathrm{H}), 4.77(1 \mathrm{H}, \mathrm{bs}, 17-\mathrm{H})$, and $4.90(1 \mathrm{H}, \mathrm{bs}, 17-\mathrm{H})$.

ent-123-Hydroxykaur-16-ene (28). The acetate (27) (242 $\mathrm{mg}$ ) dissolved in $1 \%$ sodium hydroxide in methanol $(25 \mathrm{ml})$ was stirred at $50^{\circ} \mathrm{C}$ for $3 \mathrm{hr}$. Usual work-up gave 28 as a colorless solid, $[\alpha]_{\mathrm{D}}^{30}-0.4\left(c=1.0, \mathrm{CHCl}_{3}\right)$. High MS $(m / z)$ (Found: $\mathbf{M}^{+}$288.2442. $\mathrm{C}_{20} \mathrm{H}_{32} \mathrm{O}$ requires 288.2453). MS (m/z): $288\left(\mathrm{M}^{+}\right), 273,270,255,244,231$, 215 and 199. IR $v_{\max }^{\mathrm{KBr}} \mathrm{cm}^{-1}: 3450 . \mathrm{NMR}\left(\mathrm{CDCl}_{3}\right) \delta: 0.83$ $(3 \mathrm{H}, \mathrm{s}), 0.86(3 \mathrm{H}, \mathrm{s}), 1.20(3 \mathrm{H}, \mathrm{s}), 2.62(1 \mathrm{H}, \mathrm{t}, J=4.4 \mathrm{~Hz}$, $13-\mathrm{H}), 3.80(1 \mathrm{H}, \mathrm{t}, J=4.7 \mathrm{~Hz}, 12-\mathrm{H}), 4.76(1 \mathrm{H}, \mathrm{bs}, 17-\mathrm{H})$, and $4.80(1 \mathrm{H}, \mathrm{bs}, 17-\mathrm{H})$.

ent-Kaur-16-en-12-one (29). To a stirred chromic acidpyridine complex ( $30 \mathrm{mg}$ of $\mathrm{CrO}_{3}$ in $1 \mathrm{ml}$ of pyridine) was added $10 \mathrm{mg}$. of $28 \mathrm{in} 0.2 \mathrm{ml}$ of pyridine. The reaction mixture was stirred at room temperature for $5 \mathrm{hr}$.

Usual work-up gave $9.5 \mathrm{mg}$ of the ketone (29) as colorless solid. $\mathrm{NMR}\left(\mathrm{CDCl}_{3}\right) \delta: 0.80(3 \mathrm{H}, \mathrm{s}), 0.87(6 \mathrm{H}, \mathrm{s}), 3.21$. $(1 \mathrm{H}, \mathrm{d}, J=4 \mathrm{~Hz}, 13-\mathrm{H}), 4.86(1 \mathrm{H}, \mathrm{s}, 17-\mathrm{H})$ and $4.98(1 \mathrm{H}, \mathrm{s}$, 17-H).
Acknowledgment. The authors are sincerely grateful to Professor N. Takahashi and Dr. N. Murofushi, The University of Tokyo for the generous gift of G. fujikuroi and valuable personal communications. This work was supported in part by a Grant-in-Aid for Scientific Research from the Ministry of Education, Science and Culture of Japan.

\section{REFERENCES}

1) M. Katsumi, "Gibberellins," ed. by S. Tamura, University of Tokyo Press, 1969, Chapter 6.

2) K. Wada, T. Imai and K. Shibata, Agric. Biol. Chem., 43, 1157 (1979).

3) J. R. Bearder, J. MacMillan and C. M. Wels and B. O. Phinney, Phytochemistry, 14, 1741 (1975).

4) B. E. Cross and A. Erasmuson, J. Chem. Soc., Chem. Commun., 1013 (1978).

5) N. Murofushi, S. Nagura and N. Takahashi, Agric. Biol. Chem., 43, 1159 (1979).

6) E. Fujita, T. Fujita and H. Katayama, Tetrahedron, 26, 1009 (1970).

7) J. R. Cannon, P. W. Chow, P. R. Jefferies and G. V. Meehan, Aust. J. Chem., 19, 861 (1966).

8) N. Takahashi, in "Gibberellins," ed. by S. Tamura, University of Tokyo Press, 1969, pp. $150 \sim 158$

9) R. Binks, J. MacMillan and R. J. Pryce, Phytochemistry, 8, 271 (1969).

10) J. R. Bearder, F. G. Dennis, Jr, J. MacMillan, G. C. Martin and B. O. Phinney, T. Letters, 669 (1975).

11) G. C. Martin, F. G. Dennis, Jr, P. Gaskin and J. MacMillan, Phytochemistry, 16, 605 (1977).

12) J. MacMillan and R. H. Walker, J. Chem. Soc., Perkin Trans. I, 1272 (1972).

13) D. M. Harrison and J. MacMillan, J. Chem. Soc. (C), 631 (1971).

14) H. Fukui, R. Nemori, K. Koshimizu and $Y$. Yamazaki, Agric, Biol. Chem., 41, 175 (1977).

15) J. St. Pyrek, Tetrahedron, 26, 5029 (1970).

16) A. J. McAlees and R. McCrindle, Can. J. Chem., 51, 4103 (1973). 